\title{
Oral and pharyngeal transit in functional heartburn
}

\author{
Rachel Aguiar CASSIANI and Roberto Oliveira DANTAS
}

Received: 19 November 2019

Accepted: 17 January 2020

\begin{abstract}
Background - Gastroesophageal reflux disease is associated with slower transit of the bolus through the pharynx and upper esophageal sphincter. Functional heartburn has similar symptoms to gastroesophageal reflux disease, however, the symptoms are not caused by reflux. Objective - The aim of this investigation was to evaluate oral and pharyngeal transit in patients with functional heartburn, with the hypothesis that, similar to patients with gastroesophageal reflux disease, they have changes in pharyngeal and upper esophageal sphincter transit time. Methods - Oral and pharyngeal transit was evaluated by videofluoroscopy in eight women with functional heartburn, five with mild dysphagia for solid foods, and 12 female controls. Controls and patients swallowed in duplicate $5 \mathrm{~mL}$ and $10 \mathrm{~mL}$ of liquid and paste boluses. Results - No difference in the oral or pharyngeal transit time was found between patients and controls. No aspiration of bolus into the airways was detected in any individual. Pharyngeal residues were detected in the same proportion of swallows, in patients (12.5\%) and controls (15.0\%), after swallows of $10 \mathrm{~mL}$ paste bolus. Conclusion - Oral, pharyngeal and upper esophageal sphincter transit time are similar in patients with functional heartburn to healthy controls.
\end{abstract}

HEADINGS - Heartburn. Deglutition. Upper esophageal sphincter. Gastroesophageal reflux.

\section{INTRODUCTION}

Heartburn may be caused by conditions such as erosive reflux disease (ERD), non-erosive reflux disease (NERD), hypersensitive esophagus (HE) and functional heartburn (FH). The diagnosis of each of these diseases is made by clinical manifestations, upper endoscopy and by esophageal 24-hour $\mathrm{pH}$ or $\mathrm{pH} / \mathrm{impedance}$ monitoring ${ }^{(1)}$. FH is a functional esophageal disease characterized by heartburn, failure to respond to proton pump inhibitor therapy, normal esophageal endoscopy, normal 24 hours $\mathrm{pH}$ monitoring and a negative symptom-reflux association ${ }^{(1-4)}$. Although FH has similar symptoms to gastroesophageal reflux disease (GERD), it is not considered as consequence of gastroesophageal reflux, and is investigated by the same sequence of tests ${ }^{(1-5)}$.

GERD is associated with changes in the pharyngeal phase of swallowing, with longer transit time through the pharynx and the upper esophageal sphincter ${ }^{(6,7)}$. It is possible that this slower transit time causes dysphagia, a common complaint in patients with GERD $^{(7-10)}$, mainly in those with esophagitis ${ }^{(7)}$.

This investigation evaluated the oral and pharyngeal phases of liquid and paste swallow in patients with FH. The hypothesis was that, similar to GERD, FH is also associated with changes in the pharyngeal phase of swallowing.

\section{METHODS}

Videofluoroscopic evaluation of swallowing was performed in eight patients with $\mathrm{FH}$ and in 12 healthy controls.

Patients with $\mathrm{FH}$ had the symptom at least three times a week for more than six months, a normal endoscopic examination, normal esophageal manometric examination, a 24-hour esophageal $\mathrm{pH}$ monitoring $(5 \mathrm{~cm}$ from the lower esophageal sphincter) showing a $\mathrm{pH}<4$ below $4.2 \%$ of the time, and a negative symptom-reflux association. Six patients had cough and five had mild dysphagia for solid foods. Dysphagia was evaluated by the answer to the question "Do you have swallowing difficult". If the answer was "yes" they evaluated the intensity of dysphagia by the classification mild, moderate, severe, which reflect they own perception of the intensity of the problem, and if the difficult was for liquid and/or solid foods. All FH patients were women, aged $41 \pm 12$ years, median $42(25-56)$ years. They did not have any other esophageal or gastrointestinal disorders, or any cardiac, endocrinological or neurologic disease, and were in treatment with proton pump inhibitors without good response, in the outpatient clinic of the hospital. They were instructed to refrain from taking any medication for at least seven days before the esophageal motility testing, 24 hours $\mathrm{pH}$ monitoring, and the videofluoroscopic evaluation.

The control group consisted of 12 women, aged $53 \pm 15$ years, median 54 (29-72) years. They were asymptomatic, did not have swallowing difficulties, or any gastrointestinal, cardiac, endocrinological or neurological disease and did not take medications. The study was approved by the Research Ethics Committee of the hospital (IRB 5703/2007) and all patients and volunteers gave written informed consent to participate in the investigation. None of the individuals included in the investigation had a drinking or smoking habit.

Manometry, $\mathrm{pH}$-metry and videofluoroscopy were performed as previously described ${ }^{(7)}$. Manometry and pH-metry was performed in the patients with heartburn only. Manometry was performed with water-perfused system to evaluate the esophageal motility and identify the esophageal-gastric junction. The $\mathrm{pH}$ sensor was placed $5 \mathrm{~cm}$ proximal to the esophageal-gastric junction and a 24-hours esophageal $\mathrm{pH}$ monitoring was conducted.

Declared conflict of interest of all authors: none

Disclosure of funding: no funding received

Dantas RO is a member of the Board of Directors of the International Dysphagia Diet Standardisation Initiative (IDDSI), Brisbane, Australia.

Universidade de São Paulo, Faculdade de Medicina de Ribeirão Preto, Departamento de Clínica Médica, Ribeirão Preto, SP, Brasil.

Corresponding author: Roberto Oliveira Dantas. E-mail: rodantas@fmrp.usp.br 
Videofluoroscopy was done with an Arcomax angiograph unit (Phillips, model BV 300, Veenpluis, The Netherlands). The images were recorded at 30 frames/second on the unit EDSR 100, v1.2 Everfocus (Taipei, Taiwan), and analyzed on the monitor DVR of the same manufacturer, with the digital clock of the apparatus indicating time in minutes, seconds and the number of frames on each video frame.

In the videofluoroscopic test volunteers and patients performed non-cued swallows, in duplicate, of $5 \mathrm{~mL}$ and $10 \mathrm{~mL}$ liquid and paste boluses. Liquid bolus was a liquid barium sulfate (Bariogel ${ }^{\circledR}$ $100 \%$, laboratory Cristália, Itapira, São Paulo, Brazil) which was given to the individuals by a graduate syringe, and the paste bolus was prepared with $30 \mathrm{~mL}$ of liquid barium mixed with $3 \mathrm{~g}$ of food thickner Nutilis (Cuyk Nutricia BV, Cuyk, The Netherlands) given to the individuals using a spoon. The test was performed with subjects in the sitting position and images of the mouth, pharynx and proximal esophagus captured in right-lateral position. The liquid bolus was classified as level 3 (moderately thick) and the paste bolus as level 4 (extremely thick) according to the flow test proposed by the International Dysphagia Diet Standardization Initiative (IDDSI) ${ }^{(11)}$.

It were timed the onset of propulsive tongue tip movement at the maxillary incisors, passage of the bolus head through the fauces, passage of the bolus tail through the fauces, onset and end of hyoid movement, onset and offset of upper esophageal sphincter (UES) opening.

These times were used to calculate oral and pharyngeal transit time: oral transit time - tongue tip at incisors to passage of the bolus tail through the fauces; pharyngeal transit time - bolus tail at fauces to offset of the UES opening; pharyngeal clearance - bolus head at fauces to the offset of the UES opening; UES opening (transit) - time interval between the onset and offset of UES opening; duration of hyoid movement - time interval between the beginning and end of hyoid movement; oropharyngeal transit time - tongue tip at incisors to the offset of the UES opening.

Statistical analysis was performed by a linear mixed-effects model (random and fixed effects) ${ }^{(12)}$. The model adjustment was done using proc mixed of SAS version $9.2^{(13)}$. The results are reported as means and standard deviations (SD), in seconds, unless otherwise stated.

\section{RESULTS}

There was no difference in oral or pharyngeal transit duration between FH and controls with liquid (TABLE 1) and paste (TABLE 2) swallows.

No aspiration of bolus into the airways was detected in any individual. Pharyngeal residues were detected in $12.5 \%$ of swallows in patients and $15.0 \%$ of swallows in controls, after swallows of 10 $\mathrm{mL}$ paste bolus $(P>0.10)$.

\section{DISCUSSION}

Our findings in patients with FH lead different conclusions to those described in patients with GERD. In GERD it takes longer for the bolus to move from the pharynx to the proximal esophagus $^{(6,7)}$. As FH patients have symptoms but do not have excessive esophageal acidic exposure, the results suggested that the pres-

TABLE 1. Oral and pharyngeal transit time, in seconds, in patients with functional heartburn $(\mathrm{FH}, \mathrm{n}=8)$ and controls $(\mathrm{n}=12)$, after $5 \mathrm{~mL}$ and $10 \mathrm{~mL}$ liquid swallows. Mean (SD).

\begin{tabular}{|c|c|c|c|c|c|c|}
\hline & \multicolumn{3}{|c|}{$5 \mathrm{~mL}$} & \multicolumn{3}{|c|}{$10 \mathrm{~mL}$} \\
\hline & Controls & FH & $P$-value & Controls & FH & $P$-value \\
\hline OTT & $0.66(0.33)$ & $0.62(0.22)$ & 0.82 & $0.48(0.19)$ & $0.59(0.39)$ & 0.67 \\
\hline PC & $0.70(0.19)$ & $0.77(0.19)$ & 0.31 & $0.70(0.16)$ & $0.66(0.14)$ & 0.50 \\
\hline $\mathrm{HM}$ & $0.91(0.30)$ & $0.90(0.27)$ & 0.92 & $0.79(0.19)$ & $0.79(0.16)$ & 0.99 \\
\hline OPTT & $1.07(0.33)$ & $1.03(0.29)$ & 0.77 & $0.87(0.22)$ & $0.76(0.25)$ & 0.15 \\
\hline
\end{tabular}

OTT: oral transit time; PTT: pharyngeal transit time; PC: pharyngeal clearance; HM; hyoid movement; UESO: upper esophageal sphincter opening; OPTT: oropharyngeal transit time.

TABLE 2. Oral and pharyngeal transit time, in seconds, in patients with functional heartburn $(\mathrm{FH}, \mathrm{n}=8)$ and controls $(\mathrm{n}=12)$, after $5 \mathrm{~mL}$ and $10 \mathrm{~mL}$ swallows of paste bolus. Mean (SD).

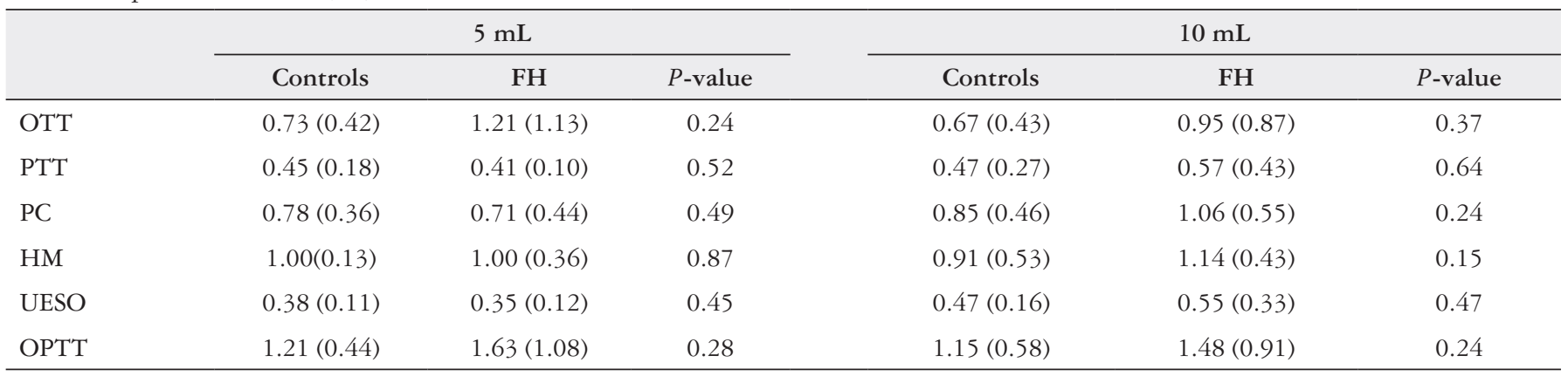

OTT: oral transit time; PTT: pharyngeal transit time; PC: pharyngeal clearance; HM; hyoid movement; UESO: upper esophageal sphincter opening; OPTT: oropharyngeal transit time. 
ence of acid inside the esophagus in GERD may cause functional changes in the upper digestive tract. Although there are few reports on these alterations, we may speculate that these changes occur mainly in the $\operatorname{UES}^{(7,14,15)}$, and due to the presence of superficial esophageal mucosal afferent nerves in cases of NERD ${ }^{(16)}$. In FH, afferent nerves are deep within the esophageal mucosa, more alike with that of healthy individuals ${ }^{(17)}$, and the esophagus is more sensitive to mechanical than acid stimuli ${ }^{(4,5)}$, i.e., esophageal distention and smooth muscle contraction ${ }^{(4)}$. It is important to consider that many symptoms attributed to gastroesophageal reflux, may be caused by a group of syndromes of different pathophysiologies ${ }^{(18)}$.

The slower pharyngeal and UES transit time may be one of the causes of dysphagia in patients with GERD, a complaint reported by almost half of the patients ${ }^{(7-9)}$. However, these changes do not explain the symptom of dysphagia reported by $62.5 \%$ of patients with FH in this investigation. Esophageal hypersensitivity to both acid and mechanical stimuli is a possible explanation for dysphagia in these patients ${ }^{(4,5)}$

Heartburn in $\mathrm{FH}$ is not related with episodes of gastroesophageal reflux. Then, suggests the occurrence of esophageal hypersensitivity to esophageal distention and/or smooth muscle contraction, but abnormalities in the central nervous system cannot be ruled out. The transient potential vanilloid subtype 1 receptor (TRPV1) is involved in esophageal hypersensitivity in these patients ${ }^{(4)}$.

There is no good evidence to support the use of neuromodulators or psychological interventions in $\mathrm{FH}$, to address the gut-brain axis disturbance associated with the disease ${ }^{(5)}$. TRPV1 antagonists would be a possibility in this sense $\mathrm{e}^{(4)}$. The treatment should be tailored taking in consideration the pathophysiology and manifestations of each member of the gastroesophaeal reflux syndrome. Proton pump inhibitors is not always the best choice for the treatment of $\mathrm{FH}$, as it may result in over usage of antisecretory agents $^{(18)}$. In addition, anxiety, hypervigilance, visceral and central hypersensitivity have modulating effects on symptom severity which should be considered in a personalized approach to managing $\mathrm{FH}$ patients ${ }^{(18)}$.

This investigation has some limitations. The number of patients with FH was small, however it was enough to draw valid conclusions about oral and pharyngeal transit. The inclusion criteria of patients with FH cause some limitations, in terms of diagnosis and duration of the disease. Our study group was composed of women only, since these were the patients treated for FH at the Division of Gastroenterology of the hospital during the time of investigation. Gender is known to influence videofluoroscopic results ${ }^{(19)}$, and the control group was composed for women only. Finally, the effects of aging on oral-pharyngeal transit time has been recently reviewed ${ }^{(20)}$. The conclusion was that bolus transit times do not appear to change with age, however tended to have a delayed swallow response times and longer duration of UES opening. In this investigation no difference of the swallowing transit duration was found between patients and controls, thus the possibility that the age has influence on the results is not likely. The influence of aging on the swallowing is seen mainly in individuals older than 70 years old ${ }^{(20)}$.

In conclusion, in this investigation oral and pharyngeal transit time of patients with $\mathrm{FH}$ did not differ from that of healthy volunteers.

\section{Authors' contribution}

Cassiani RA and Dantas RO had participation in study planning, investigation, data collection and discussion of results, in addition to manuscript preparation and in decision to submit to publication.

\section{Orcid}

Rachel Aguiar Cassiani: 0000-0002-6100-7025.

Roberto Oliveira Dantas: 0000-0003-2183-0815.

Cassiani RA, Dantas RO. Trânsitos oral e faríngeo na pirose funcional. Arq Gastroenterol. 2020;57(2):150-3.

RESUMO - Contexto - A doença do refluxo gastroesofágico está associada ao trânsito mais lento do bolo deglutido pela faringe e esfíncter superior do esôfago. Pirose funcional tem sintomas similares aos de doença do refluxo gastroesofágico, entretanto eles não são consequência de refluxo. Objetivo - Como na pirose funcional os sintomas são semelhantes aos da doença do refluxo gastroesofágico, o objetivo desta investigação foi avaliar a duração do trânsito do bolo deglutido pela boca, faringe e esfíncter superior do esôfago em pacientes com pirose funcional, com a hipótese de que esses pacientes também apresentem alteração no trânsito. Métodos - Pelo método videofluoroscópico foi avaliado o trânsito oral e faríngeo de oito pacientes do sexo feminino com pirose funcional, cinco com disfagia leve para alimentos sólidos, e 12 indivíduos controles do sexo feminino. Controles e pacientes deglutiram em duplicata $5 \mathrm{~mL}$ e $10 \mathrm{~mL}$ de bolos com a consistências líquida e pastosa. Resultados - Com bolo líquido e pastoso não houve diferença na duração do trânsito oral, faríngeo e pelo esfíncter superior do esôfago entre controles e pacientes. Não houve aspiração do bolo para as vias aéreas em nenhum indivíduo. Os resíduos faríngeos foram observados na mesma proporção das deglutições em pacientes (12,5\%) e controles (15\%), com a deglutição de $10 \mathrm{~mL}$ de bolo pastoso. Conclusão - A duração do trânsito oral, faríngeo e pelo esfíncter superior do esôfago foi semelhante nos pacientes com pirose funcional e controles.

DESCRITORES - Azia. Deglutição. Esfíncter esofágico superior. Refluxo gastroesofágico. 


\section{REFERENCES}

1. Kandulski A, Moleda L, Müler-Schilling M. Diagnostic investigations of gastroesophageal reflux disease; who and when to refer and for what test? Visc Med. 2018;34:97-100.

2. Aziz Q, Fass R, Gyawali CP, Miwa H, Pandolfino JE, Zerbib F. Esophageal disorders. Gastroenterology. 2016;150:1368-79.

3. Hachem C, Shaheen N. Diagnosis and management of functional heartburn. Am J Gastroenterol. 2016;111:53-61.

4. Kondo T, Miwa H. The role of esophageal hypersensitivity in functional heartburn. J Clin Gastroenterol. 2017;51:571-8.

5. Lee YY, Wu JCY. Management of patients with functional heartburn. Gastroenterology. 2018;154:2018-21.

6. Mendell DA, Logemann JA. A retrospective analysis of the pharyngeal swallow in patients with clinical diagnosis of GERD compared with normal controls: a pilot study. Dysphagia. 2002;17:220-6.

7. Cassiani RA, Mota GA, Dantas RO. Oral and pharyngeal transit in gastroesophageal reflux disease. Esophagus. 2015;12:345-51.

8. Vakil NB, Traxler B, Levine D. Dysphagia in patients with erosive esophagitis: prevalence, severity, and response to proton pump inhibitor treatment. Clin Gastroenterol Hepatol. 2004;2:665-8.

9. Triadafilopoulos G. Nonobstructive dysphagia in reflux esophagitis. Am J Gastroenterol. 1989;84:614-8.

10. Kidambi T, Toto E, Ho N, Taft T, Hirano I. Temporal trends in the relative prevalence of dysphagia in reflux esophagitis. World J Gastroenterol. 2012;18:4335-41.

11. Cichero JAY, Lam P, Steele CM, Hanson B, Chen J, Dantas RO, et al. Development of international terminology and definitions for texture-modified foods and thickened fluids used in dysphagia management. The IDDSI framework. Dysphagia. 2017;32:293-314.
12. Schall R. Estimation in generalized linear models with random effects. Biometrika. 1991;78:719-27.

13. Littell RC, Milliken GA, Stroup WW, Wolfinger RD. SAS system of non-linear mixed models. Cary, NC: SAS Institute Inc.; 1996.

14. Dantas RO, Cassiani RA. Upper esophageal sphincter dysfunction in gastroesophageal reflux disease. Dysphagia. 2019;34:942-3.

15. Nativ-Zeltzer N, Rameau A, Kun MA, Kaufman M, Belafsky PC. The relationship between hiatal hernia and cricopharyngeus dysfunction. Dysphagia. 2019; 34:391-6.

16. Woodland P, Shen Ooi JL, Grassi F, Nikaki K, Lee C, Evans JA, et al. Superficial esophageal mucosal afferent nerves may contribute to reflux hypersensitivity in nonerosive reflux disease. Gastroenterology. 2017;153:1230-9.

17. Nikaki K, Woodland P, Lee C, Ghisa M, Martinelli C, Savarino E, et al. Esophageal mucosal innervation in functional heartburn: closer to healthy asymptomatic subjects than to non-erosive reflux disease. Neurogastroenterol Motil. 2019;31:e13667.

18. Katzka DA, Pandolfino JE, Kahrilas PJ. Phenotypes of gastroesophageal reflux disease: where Rome, Lyon, and Montreal meet. Clin Gastroenterol Hepatol. 2020;18:767-76.

19. Dantas RO, Cassiani RA, Santos CM, Gonzaga CG, Alves LMT, Mazin SC. Effect of gender on swallow duration assessed by videofluoroscopy. Dysphagia. $2009 ; 24: 280-4$

20. Namasivayam-MacDonald AM, Barbon CEA, Steele CM. A review of swallow timing in the elderly. Physiol Behav. 2018;184:12-6. 